\title{
Frost Susceptibility of Recycled Aggregate
}

\section{M.O'Mahony}

\begin{abstract}
An important requirement for sub-base and capping material in road construction is that it should not be susceptible to frost. Therefore if recycled aggregate is to be used in either of these cases, it also must not be susceptible to frost. Frost susceptibility is largely dependent on the flow of water to an aggregate from the soil be low but tests were also conducted to determine if frost susceptibility was influenced by the moisture content of an aggregate at the time of placement. Crushed concrete was tested to rep resent a high quality recycled aggregate whereas demolition debris (an unsorted demolition waste material) was much lower in quality.
\end{abstract}

The results, presented in the paper, show the response of these recycled aggregates to frost and highlight a strong relationship between frost susceptibility and moisture content for crushed concrete, in particular. The aim of the research was to provide additional information on the behaviour of recycled aggregates in freezing conditions and to compare this response with that of natural aggregates.

\section{Introduction}

Materials placed within 450mm of any road surface should not be susceptible to frost as defined by the Transport and Road Research Laboratory test described by Roe and Webster (1984). It has been found that there is an increase in the number of road failures during and following severe winters. This deterioration can occur in three ways.

a) When water penetrates the road surface, damage can be caused by the expansion of water as ice forms. This type of deterioration can be avoided by better construction and maintenance techniques and particularly if the road is adequately sealed.

b) A more serious type of damage can be caused to road surfaces by the formation of ice lenses in the lower layers which cause the road to heave.

c) When a pavement has been damaged by either of the ways described in a) and b), a further loss of strength may occur when the ice thaws because the material will have a higher moisture content and therefore reduced bearing capacity. 
Point $b$ ) is the most relevant when discussing unbound aggregates placed in the lower layers of a road pavement such as in the sub-base layer or the capping layer. It is imperative that these layers include materials which are not susceptible to frost.

The pore spaces between the unbound aggregate particles are generally large enough to accommodate the expansion of water contained in them when freezing starts. However, as the zero isotherm penetrates deeper into the pavement, a pressure gradient is set up between the ice in the upper layers and the water table. Under this pressure gradient, water ascends towards the zero isotherm by means of capillary action. The pore spaces do not have the capacity to hold this extra water when it expands on freezing and so ice lenses develop. Two important factors which effect this flow of water are the quantity of water present and the amount of fine particles in the material (less than $75 \mu \mathrm{m}$ ). The greater the amount of these fine particles, the easier water will be able to ascend by capillary action.

The object of this research was to examine the ability of recycled aggregates to match the performance of their natural counterparts with respect to the requirements of unbound aggregates for use in sub-base and capping layers. This included an examination of the frost heave of crushed concrete and demolition debris and a comparison of the results with those of limestone.

\section{Experimental Work}

The frost heave experiments were carried out in a frost heave apparatus as described by Roe and Webster (1984). The experiments involved placing compacted specimens of aggregate, of height $154 \mathrm{~mm}$ and diameter $100 \mathrm{~mm}$, in a chamber with the lower ends of the specimens in indirect contact with water by means of a porous disc. The specimens were surrounded by dry pea gravel and the top of the specimens were not covered. The chamber was closed and the temperature of the water was maintained at $4^{\circ} \mathrm{C}$ but the air temperature was reduced well below freezing to $-17^{\circ} \mathrm{C}$. The heave was measured by the movement of brass rods placed touching the top of the samples and protruding through the top of the chamber.

Although it is recommended by Roe and Webster (1984) that samples be tested at optimum moisture content $(\mathrm{OMC})$ and peak dry density $\left(\rho_{\mathrm{d}}\right)$, testing at $0.5 \mathrm{OMC}$ and $1.5 \mathrm{OMC}$ was also 
attempted. Some adjustment was made to these moisture contents when stability of the compacted samples could not be achieved.

\subsection{Test conditions of limestone specimens}

Three samples at each test condition were tested in accordance with Roe and Webster (1984).

Table 1 includes the moisture content and density values at which the limestone specimen were tested.

\begin{tabular}{|l|l|l|l|l|l|}
\hline \multicolumn{3}{|c|}{ COMPACTION TARGET VALUES } & \multicolumn{2}{c|}{ MEASURED VALUES } \\
\hline Test Ref. No & $\begin{array}{l}\boldsymbol{\rho} \text { b } \\
\left(\mathbf{k g} / \mathbf{m}^{3}\right)\end{array}$ & $\begin{array}{l}\text { Moisture } \\
\text { Content }(\%)\end{array}$ & $\boldsymbol{\rho d}\left(\mathbf{k g} / \mathbf{m}^{3}\right)$ & $\begin{array}{l}\text { Moisture } \\
\text { Content }(\%)\end{array}$ & $\boldsymbol{\rho d}\left(\mathbf{k g} / \mathbf{m}^{\mathbf{3}}\right)$ \\
\hline L1 & 2361 & 1.75 & 2320 & $1.98(0.56 \mathrm{OMC})$ & 2074 \\
\hline L2 & 2401 & 3.5 & 2320 & $3.34(0.95$ OMC $)$ & 2316 \\
\hline L3 & 2442 & 5.25 & 2320 & $3.8(1.08$ OMC $)$ & 2071 \\
\hline
\end{tabular}

Table 1. Test conditions of the limestone specimens

Note: $\rho_{b}$ and $\rho_{d}$ denote bulk density and dry density respectively.

The target density and moisture content for L2 were peak dry density and OMC. Although samples L1 and L3 were prepared at different moisture contents, the target density remained at $2320 \mathrm{~kg} ! \mathrm{m}^{3}$ so that stable samples could be obtained. However, it was clear during compaction that this density could not be achieved using these te st conditions. Compaction of these samples was continued until an increase in compaction time did not change the volume of the material. When this stage was reached, the specimens were extruded. As they remained stable, it was decided to use these samples in the frost heave test. It can be seen in Table 1 that L 3 had a moisture content much lower than the target value. This was due to a bleeding from the sample during mixing.

\subsection{Test conditions of the demolition debris specimens}

Initially, the choice of test conditions for demolition debris was similar to that of limestone. The demolition debris had a water absorption value of $8 \%$ which was much higher than the value of $0.45 \%$ for limestone and consequently the moisture contents of the samples of 
demolition debris were also higher. However, it was difficult to obtain stable samples at a moisture content of $0.5 \mathrm{OM} \mathrm{C}$. The $\mathrm{OMC}$ for demolition debris was found to be $13 \%$ using the BS 5835 (1980) compaction test and consequently 0.5 OMC was lower than the water absorption value. Hence, there was not enough water present in these samples to help compaction. It was also impossible to obtain stable samples of the material at a moisture content of 1.5 OMC. To rectify this situation, new target moisture contents were calculated as follows:-

Low moisture content $=\mathrm{OMC}-\left(\mathrm{OMC}-\mathrm{W}_{\mathrm{a}}\right) / 2$

High moisture content $=\mathrm{OMC}+\left(\mathrm{OMC}-\mathrm{W}_{\mathrm{a}}\right) / 2$

where $\mathrm{W}_{\mathrm{a}}$ is the water absorption of the aggregate.

It was possible to create stable samples when these moisture contents were used. The test conditions of the demolition debris specimens are listed in Table 2.

\begin{tabular}{|l|l|l|l|l|l|}
\hline \multicolumn{3}{|c|}{ COMPACTION TARGET VALUES } & \multicolumn{2}{c|}{ MEASURED VALUES } \\
\hline Test Ref. No & $\begin{array}{l}\boldsymbol{\rho} b \\
\left(\mathbf{k g} / \mathbf{m}^{\mathbf{3}}\right)\end{array}$ & $\begin{array}{l}\text { Moisture } \\
\text { Content }(\%)\end{array}$ & $\boldsymbol{\rho d}\left(\mathbf{k g} / \mathbf{m}^{\mathbf{3}}\right)$ & $\begin{array}{l}\text { Moisture } \\
\text { Content }(\%)\end{array}$ & $\boldsymbol{\rho d}\left(\mathbf{k g} / \mathbf{m}^{\mathbf{3}}\right)$ \\
\hline D1 & 2010 & 10.5 & 1820 & $10.94(0.84 \mathrm{OMC})$ & 1815 \\
\hline D2 & 2060 & 13.0 & 1820 & $13(\mathrm{OMC})$ & 1824 \\
\hline D3 & 2090 & 15.0 & 1820 & $14.6(1.12 \mathrm{OMC})$ & 1802 \\
\hline
\end{tabular}

Table 2. Test conditions of the demolition debris specimens

\subsection{Test conditions of the crushed concrete specimens}

The crushed concrete had a water absorption value lower than 0.5 OMC so the same approach was adopted as that for limestone i.e. the target moisture content values were 0.5 OMC, OMC and 1.5 OMC. When trial specimens were prepared, it was concluded, after several attempts, that the target density of $2000 \mathrm{~kg} / \mathrm{m}^{3}$ for $\mathrm{C} 3$ could not be achieved. Therefore the target value for $\mathrm{C} 3$ was changed to the maximum density which could be obtained for this test condition in the trial samples. The moisture content and density values of the cru shed concrete samples are listed in Table 3. 


\begin{tabular}{|l|l|l|l|l|l|}
\hline \multicolumn{3}{|c|}{ COMPACTION TARGET VALUES } & \multicolumn{2}{c|}{ MEASURED VALUES } \\
\hline Test Ref. No & $\begin{array}{l}\boldsymbol{\rho}_{\mathbf{b}} \\
\left(\mathbf{k g} / \mathbf{m}^{\mathbf{3}}\right)\end{array}$ & $\begin{array}{l}\text { Moisture } \\
\text { Content }(\%)\end{array}$ & $\boldsymbol{\rho}_{\mathbf{d}}\left(\mathbf{k g} / \mathbf{m}^{\mathbf{3}}\right)$ & $\begin{array}{l}\text { Moisture } \\
\text { Content }(\%)\end{array}$ & $\boldsymbol{\rho}_{\mathbf{d}}\left(\mathbf{k g} / \mathbf{m}^{\mathbf{3}}\right)$ \\
\hline C1 & 2103 & 5.13 & 2000 & $6.3(0.6 \mathrm{OMC})$ & 1838 \\
\hline C2 & 2205 & 10.25 & 2000 & $8.3(0.8$ OMC $)$ & 2002 \\
\hline C3 & 2125 & 15.5 & 2000 & $13.2(1.28$ OMC $)$ & 1904 \\
\hline
\end{tabular}

Table 3. Test conditions of the crushed concrete specimens

\section{Results and Discussion}

The following classification system was presented by Roe and Webster (1984). If the mean frost heave is less that $9 \mathrm{~mm}$, the material is classed as not frost susceptible. If the mean is greater than $15 \mathrm{~mm}$, the material is classed as frost susceptible. However, if the mean is in the range $9.1 \mathrm{~mm}$ to $14.9 \mathrm{~mm}$, the material shall be regarded as 'not proven' and is required to be tested at other laboratories for clarification. The results of all frost heave tests are listed in Table 4. If L2, 02 and C2 are examined firstly i.e. the specimens closest to OMC and peak density, it can be seen that the frost heave measured in the L2 samples is quite low with a mean of $3.5 \mathrm{~mm}$. However, the mean frost heave of the demolition debris (02) samples is $12.3 \mathrm{~mm}$ which indicated that it was in the 'not proven' range. The moisture content of the crushed concrete samples (C2) was 0.8 OMC which was much lower than expected. To obtain an indication of the likely frost heave at $\mathrm{OMC}$, the frost heave results were plotted against moisture content in Figure 1. By interpolation of the results, it can be estimated that a frost heave of $18 \mathrm{~mm}$ might be obtained at OMC (10\%). On this basis, crushed concrete would be classed as frost susceptible. 


\begin{tabular}{|l|l|l|l|l|l|l|}
\hline Test Ref. & Moisture & $\begin{array}{l}\text { Sample 1 } \\
\text { Heave } \\
(\mathbf{m m})\end{array}$ & $\begin{array}{l}\text { Sample 2 } \\
\text { Heave } \\
(\mathbf{m m})\end{array}$ & $\begin{array}{l}\text { Sample 3 } \\
\text { Heave } \\
(\mathbf{m m})\end{array}$ & $\begin{array}{l}\text { Mean } \\
\text { Frost } \\
\text { heave } \\
(\mathbf{m m})\end{array}$ & $\begin{array}{l}\text { Standard } \\
\text { Deviation } \\
(\mathbf{m m})\end{array}$ \\
\hline L1 & $0.56 \mathrm{OMC}$ & 5.5 & 7 & 9 & 7.2 & 1.43 \\
\hline L2 & $0.95 \mathrm{OMC}$ & 5 & 2.5 & 3 & 3.5 & 1.08 \\
\hline L3 & $1.08 \mathrm{OMC}$ & 4 & 3.5 & 3 & 3.5 & 0.41 \\
\hline D1 & $0.84 \mathrm{OMC}$ & 12 & 12.5 & 13 & 12.5 & 0.41 \\
\hline D2 & $1.00 \mathrm{OMC}$ & 12 & 12 & 13 & 12.3 & 0.47 \\
\hline D3 & $1.12 \mathrm{OMC}$ & 10.5 & 10.5 & 11 & 10.7 & 0.48 \\
\hline C1 & $0.6 \mathrm{OMC}$ & 4 & 3.5 & 3.5 & 3.7 & 0.24 \\
\hline C2 & $0.9 \mathrm{OMC}$ & 10 & 10 & 13 & 11 & 1.41 \\
\hline C3 & $1.28 \mathrm{OMC}$ & 30 & 30 & 33 & 31 & 1.41 \\
\hline
\end{tabular}

Table 4. Frost heave results

It is apparent in Figure I that there is a strong relationship between moisture content and frost heave for the crushed concrete samples where, as the moisture content increases so does frost heave. The relationships for demolition debris and limestone are much different, in that as the moisture content increases, frost heave reduces to a much lesser extent. Further work would need to be conducted to investigate these relationships further. Considering the high frost heave of $30 \mathrm{~mm}-33 \mathrm{~mm}$ recorded in the crushed concrete samples, it can only be concluded that it would be unwise to place this material in areas where water is likely to ingress into the pavement. Increasing moisture content in the other materials does not appear to increase the probability of frost heave. 


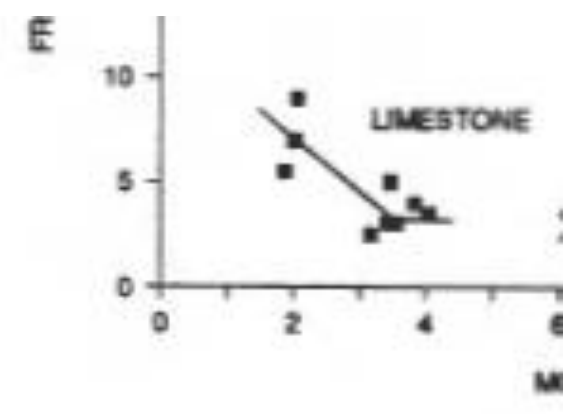

\section{Figure 1. Relationship between frost heave and moisture content}

The two main factors effecting frost heave are considered to be the quantity of water below the layer of material which might ascend when freezing starts and the amount of fine material in the sample. Normally high frost heave is associated with large quantities of fines in the material (Jones and Hurt, 1980). The proportion of the particles passing the $75 \mu \mathrm{m}$ sieve was close to $10 \%$ which is the maximum percentage allowed for sub-base material according to the Specification for Roadworks (1981). However, the fines content of the crushed concrete samples was not significantly different to the other materials so this could not be the reason for the higher frost heave exhibited.

The moisture content present in the aggregate at placement can be considered further. It can be divided into two pans; the first being the water absorbed by the panicles and the other the free water between the particles. It is likely, upon freezing, that the free water would be the main cause of any global damage to the layer particularly by the fom1ation of ice lenses. In the case of the crushed concrete at 1.28 OMC, it was calculated that the water between the particles would induce a heave of $2 \mathrm{~mm}-4 \mathrm{~mm}$ upon freezing. A volume increase of water upon freezing of $9 \%$ was used, as suggested by Neville (1973), . The heave calculated is relatively small in comparison with the heave of $30 \mathrm{~mm}-33 \mathrm{~mm}$ measured in the samples and therefore does not serve to clarify this excessive frost heave. Additional work would be required to investigate 
the susceptibility of crushed concrete to frost. It was surprising that the demolition debris, which was a lower quality aggregate with a higher water absorption, did not exhibit high frost heave values similar to those of crushed concrete. It should be noted that these results were also more consistent than those of the other materials.

Croney and Jacobs ( 1967) found that the addition of cement to aggregates reduced frost heave. It was found by Sweere (1989) in a field trial that crushed concrete and demolition debris, used as sub-base materials in road pavements, exhibited better resistance to rutting three months after construction that when the material was first placed. This led Sweere (1989) to believe that recycled aggregates had a self-cementing effect. It may be that this binding effect might also reduce frost heave and so it is proposed to examine this in a later study. In general, crushed concrete and demolition debris both contain relatively large quantities of cement but the selfcementing effect might not be easily identified in the Roe and Webster (1984) test because the samples are tested directly after placement.

\section{Conclusions}

(i) On the basis of the results presented in this paper. limestone would be classed as not frost susceptible but it was apparent that crushed concrete would be highly susceptible to frost. The frost heave results of demolition debris indicated that it was in the inconclusive range but its results were more consistent than those of the limestone or crushed concrete. Further testing at other laboratories would be required to confirm its susceptibility to frost.

(ii) Although the frost heave of crushed concrete appeared to be directly influenced by the initial moisture content of the specimens, the increase in volume of the material due to the expansion of this water on freezing was calculated and found to be relatively insignificant. The apparent dependence of frost heave on the initial moisture content was not noticed for tests conducted on limestone and demolition debris and further testing therefore would be required to determine other contributing factors to frost heave.

(iii) Following the conclusion of Sweere (1989) that recycled aggregates exhibit a selfcementing effect sometime after placement, it is proposed to examine whether this effect would also improve the susceptibility of these materials to frost. 


\section{REFERENCES}

British Standard 5835 (1980) Compactibility test for graded aggregates. Part I. British Standards Institution. London.

Croney, D. and Jacobs, J.C. (1967) The frost susceptibility of soils and road materials. LR90. Transport and Road Research Laboratory.

Jones, R.H. and Hurt, K.G. (1980) The prediction of the frost susceptibility of limestone and sub-base materials. The Highway Engineer.

Neville, A.M. ( 1973) Properties of Concrete. Pitman. London.

Roe, P.G. and Webster, D.C. (1984) Specification for the TRRL frost heave test. SR829. Transport and Road Research Laboratory, Crowthorne, Berkshire, U.K.

Specification for Roadworks (1981) Department of the Environment. Government Publications Office. Dublin.

Sweere, G.T.H. (1989) Structural contribution of self-cementing granular bases to asphalt pavements. Proc. 3rd Symposium on Unbound Aggregates in Roads (UNBAR 3). University of Nottingham. 